\title{
Pulmonary fibrosis indicative of granulomatosis with polyangiitis initially believed to be sjögren's syndrome
}

\author{
Souhaibou Ndongo*, Abdoulaye Pouye, Emeric Azankpan, Awa Cheikh Ndao and Thérèse Moreira Diop \\ *Correspondence: sndongo_medinterne@yahoo.fr

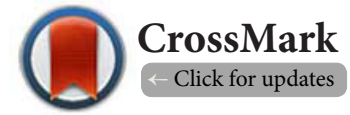

Department of Internal Medicine Inside, Le Dantec Hospital, Dakar, Senegal.

\begin{abstract}
Wegener's disease, currently called granulomatosis with polyangiitis, is a systemic necrotizing vasculitis of small vessels. It is typically associated with nodular opacity type pulmonary lesions of varying size developing towards excavation. Pulmonary fibrosis is more rarely observed. We report a case initially believed to be a Sjögren's syndrome in a 32-year old female Senegalese patient. The diagnosis of Wegener's granulomatosis was given on the basis of pulmonary fibrosis, oral ulcers, and the positivity of anti-PR3 type ANCA. The response to treatment remains favorable to this day, despite the occurrence of a secondary intercostal herpes zoster upon the use of cyclophosphamide and corticosteroids. The treatment of Sjögren's syndrome, for which the criteria were not met as it happens, may have bastardized the clinical expression of Wegener's disease.
\end{abstract}

Keywords: Sjögren's syndrome, wegener's disease, granulomatosis, pulmonary fibrosis

\section{Introduction}

Wegener's disease, currently called granulomatosis with polyangiitis, is a systemic necrotizing vasculitis of small vessels. Orthootolaryngology, lung and kidney manifestations dominate the clinical signs, although other organs may also be affected [1].

It is typically associated with nodular opacity type pulmonary lesions of varying size developing towards excavation. Pulmonary fibrosis is more rarely observed. We report a case revealed by pulmonary fibrosis, and initially believed to be a Sjögren's syndrome.

\section{Case presentation}

This case concerns a 32-year old Senegalese woman admitted for a chronic productive cough with whitish viscous sputum without fever, associated with NYHA stage I exertional dyspnea. This clinical presentation, which has been evolving since 2008, had required several hospitalizations and repeated unexpected antibiotic therapy. She was on prednisone $10 \mathrm{mg} /$ day and hydroxychloroquine $400 \mathrm{mg} /$ day for Sjögren's syndrome. Diagnosis of Sjögren's syndrome has been mentioned before admission in Internal Medicine, on the basis of dry eye and the results of salivary glands biopsy: grade II of Chisholm Masson. There was no other clinical argument, and rheumatoid factor was negative.
In her history, she did not report smoking or a profession at risk of lung disease or taking pneumotoxic medication.

The physical examination showed no abnormalities apart from diffuse wheezing in both lungs without orthopnea.

Physical examination on admission had shown no objective sign of Sjögren's syndrome. The blood count showed a white blood cell count of 7,220 cells $/ \mathrm{ml}$ with a normal formula, a hemoglobin level of $13.5 \mathrm{~g} / \mathrm{dl}$, and platelets at $331,000 \mathrm{cell} / \mathrm{s} / \mathrm{ml}$.

We noted a nonspecific biological inflammatory syndrome with an accelerated rate of sedimentation, and an increased rate of C-reactive protein. Antinuclear antibodies, extractable nuclear antigen antibodies, Cyclic citrullinated peptide antibodies and anti-native-DNA auto-antibodies were negative.

Creatinine was normal, as was $24 \mathrm{~h}$ proteinuria, transaminases and muscle enzymes. The tuberculin skin test was negative.

There was no active urinary sediment at the admission of the patient. The chest radiograph showed reticulonodular infiltrates on both sides (Figure 1). Chest computed tomography objectified a diffuse infiltrative pneumopathy with honeycomb images in favor of a pulmonary fibrosis.

Pulmonary function tests showed a mixed restrictive and obstructive type ventilatory deficit not improved by inhaled beta2. Biopsy samples taken at bronchoscopy showed signs of non-specific inflammation. 


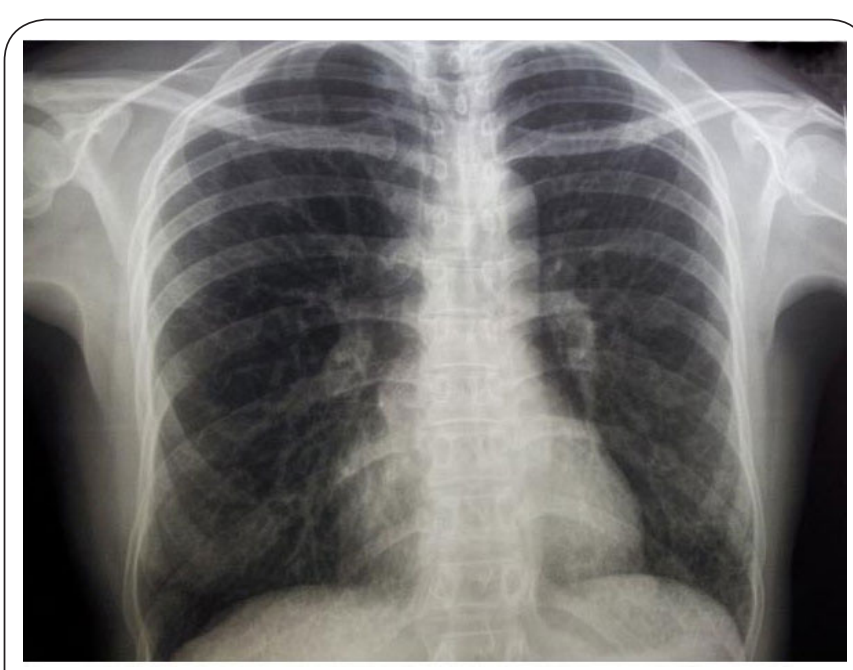

Figure 1. Chest $\mathrm{X}$ ray showed reticulonodular infiltrates on both sides.

Additional immunological tests performed upon the onset of lingual ulcers and frontal headaches highlighted positivity of anti-PR3 type ANCA. Brain MRI and CT scans of the facial bones were normal.

The diagnosis of Wegener's granulomatosis was given on the basis of pulmonary fibrosis, oral ulcers, and the positivity of anti-PR3 type ANCA. Biopsy tongue has not been realized. The response to treatment remains favorable to this day, despite the occurrence of a secondary intercostal herpes zoster upon the use of intravenous cyclophosphamide $1 \mathrm{~g}$ every month) and corticosteroids ( $1 \mathrm{mg} / \mathrm{kg} /$ day for 4 weeks then dose reduction progressively).

\section{Discussion}

The diagnosis of granulomatosis with polyangiitis was given in our patient because of the presence of 2 out of 4 ACR 1990 criteria [2]; and that of pulmonary fibrosis based on CT images [3]. Pulmonary manifestations are variable in Wegener's granulomatosis, and are generally preceded by those of the upper airway.

They are present in 50 to $75 \%$ of cases $[4,5]$. The most characteristic lesion is represented by the nodules observed in half of the cases [6-8]. The other conditions are pulmonary infiltrates in 30-50\% of cases, alveolar condensation in 30-50\% of cases, and pleural effusion in 9-28\% of cases [9]. Pulmonary fibrosis rarely reveals granulomatosis with polyangiitis. Ketata et al., reported one case in 2009 [10]. Most cases of pulmonary fibrosis described are related to $p$-ANCA vasculitis, unlike granulomatosis with polyangiitis, which is a c-ANCA vasculitis $[11,12]$. The pathogenesis of this association is still poorly understood, but the direct role of ANCA in the pathogenesis of pulmonary fibrosis is increasingly emphasized $[13,14]$.

The treatment of Sjögren's syndrome, for which the criteria were not met as it happens, may have bastardized the clinical expression of Wegener's disease.

\section{Conclusion}

This case once again confirms the multifaceted nature of lung disease in Wegener's granulomatosis with polyangiitis. Although rare, pulmonary fibrosis may reveal this vasculitis. Pathophysiological mechanisms are still poorly understood, but the direct role of ANCA is increasingly cited.

\section{Competing interests}

The authors declare that they have no competing interests.

Authors' contributions

\begin{tabular}{|l|c|c|c|c|c|}
\hline Authors' contributions & SN & AP & EA & ACN & TMD \\
\hline Research concept and design & $\checkmark$ & $\checkmark$ & -- & -- & $\checkmark$ \\
\hline Collection and/or assembly of data & $\checkmark$ & $\checkmark$ & $\checkmark$ & $\checkmark$ & $\checkmark$ \\
\hline Data analysis and interpretation & -- & -- & -- & -- & -- \\
\hline Writing the article & $\checkmark$ & $\checkmark$ & $\checkmark$ & -- & -- \\
\hline Critical revision of the article & $\checkmark$ & -- & -- & -- & -- \\
\hline Final approval of article & $\checkmark$ & $\checkmark$ & $\checkmark$ & $\checkmark$ & $\checkmark$ \\
\hline Statistical analysis & -- & -- & -- & -- & -- \\
\hline
\end{tabular}

\section{Publication history}

EIC: Fabio Angeli, University of Perugia, Italy.

Received: 29-Sep-2014 Final Revised: 28-Nov-2014

Accepted: 04-Dec-2014 Published: 10-Dec-2014

\section{References}

1. Guillevin $L$ and Terrier B. Classification des vascularites systémiques. Presse Med. 2012; 41:986-95.

2. Leavitt RY, Fauci AS, Bloch DA, Michel BA, Hunder GG, Arend WP, Calabrese LH, Fries JF, Lie JT and Lightfoot RW et al. The American College of Rheumatology 1990 criteria for the classification of Wegener's granulomatosis. Arthritis Rheum. 1990; 33:1101-7. | Article | PubMed

3. Gotway MB, Freemer MM and King TE, Jr. Challenges in pulmonary fibrosis. 1: Use of high resolution CT scanning of the lung for the evaluation of patients with idiopathic interstitial pneumonias. Thorax. 2007; 62:546-53. | Article | PubMed Abstract | PubMed Full Text

4. Hoffman GS, Kerr GS, Leavitt RY, Hallahan CW, Lebovics RS, Travis WD Rottem $M$ and Fauci AS. Wegener granulomatosis: an analysis of 158 patients. Ann Intern Med. 1992; 116:488-98. I Article I PubMed

5. Reinhold-Keller E, Beuge N, Latza U, de Groot K, Rudert H, Nolle B, Heller $\mathrm{M}$ and Gross WL. An interdisciplinary approach to the care of patients with Wegener's granulomatosis: long-term outcome in 155 patients. Arthritis Rheum. 2000; 43:1021-32. I Article I PubMed

6. Lohrmann C, Uhl M, Kotter E, Burger D, Ghanem N and Langer M. Pulmonary manifestations of wegener granulomatosis: CT findings in 57 patients and a review of the literature. Eur J Radiol. 2005; 53:471-7. | Article I PubMed

7. Cordier JF. Atteinte pulmonaire des vascularites. Rev Prat. 2008; 58:4928.

8. Brillet PY and Brauner M. Imagerie pulmonaire dans les vascularites associées aux ANCA. Presse Med. 2007; 36:907-12. | Article

9. Pagnoux $C$ and Teixeira L. Granulomatose de Wegener. Presse Med. 2007; 36:860-74.

10. Ketata W, Msaad S and Gharsalli $\mathrm{H}$ et al. Fibrose pulmonaire révélant une maladie de Wegener. Rev Mal Respir. 2009; 26:981-4.

11. Nada AK, Torres VE, Ryu JH, Lie JT and Holley KE. Pulmonary fibrosis as an unusual clinical manifestation of a pulmonary-renal vasculitis in elderly patients. Mayo Clin Proc. 1990; 65:847-56. | Article | PubMed 
Ndongo et al. Internal Medicine Inside 2014,

http://www.hoajonline.com/journals/pdf/2052-6954-2-6.pdf

12. Hervier B, Pagnoux C, Agard C, Haroche J, Amoura Z, Guillevin L and Hamidou MA. Pulmonary fibrosis associated with ANCA-positive vasculitides. Retrospective study of 12 cases and review of the literature. Ann Rheum Dis. 2009; 68:404-7. | Article | PubMed

13. Foulon G, Delaval P, Valeyre D, Wallaert B, Debray MP, Brauner M, Nicaise P, Cadranel J, Cottin V, Tazi A, Aubier M and Crestani B. ANCA-associated lung fibrosis: analysis of 17 patients. Respir Med. 2008; 102:1392-8. | Article I PubMed

14. Mouthon L. Causes et mécanismes à l'origine des vascularites. Rev Prat. 2008; 58:487-91. I Article

\section{Citation:}

Ndongo S, Pouye A, Azankpan E, Ndao AC and

Diop TM. Pulmonary fibrosis indicative of

granulomatosis with polyangiitis initially believed

to be sjögren's syndrome. Intern Med Inside. 2014;

2:6. http://dx.doi.org/10.7243/2052-6954-2-6 